\title{
Assessment of the effect of Cadmium, Copper and Lead on Soils prorperties with reference to cultivated land use in the Tropical Wet-and Dry Climate
}

\author{
Eruola, A.O. ${ }^{1}{ }^{*}$, Adetunji, M.T. ${ }^{2}$ and Azeez, A.O. ${ }^{2}$ \\ Yaba College of Technology, Yaba, Lagos State, Nigeria \\ University of Agriculture, Abeokuta, Nigeria
}

\begin{abstract}
The quest for food safety is very high in this era of environmental pollution. Incubation of the soilmetals was done in the laboratory for eight weeks to determine the effects of cadmium, copper and lead on some physical and chemical properties of soils sampled from six different cultivated land use in Abeokuta, Southwestern Nigeria in 2010 and 2011. The $\mathrm{pH}$ decreased from 7.01 to 6.65. The Effective Cation Exchange Capacities decreased from 5.97 to $4.26 \mathrm{C} \mathrm{mol} \mathrm{\textrm {kg } ^ { - 1 }}$ under single treatments for the six locations. Single metal treatments produced additive, synergistic and antagonistic responses on the residual metals on incubated soils
\end{abstract}

Keyword: Heavy metals, Incubation process, $p H$ and ECEC.

\section{Introduction}

During the last few decades, the toxicity of heavy metals has drawn attention of many environmental scientists. Heavy metal accumulation leads to the loss of agricultural yield and hazardous health effect (Chirenje et al., 2003; Ma et al., 1995). Food chain contamination by heavy metals has become a burning issue in recent years because of their potential accumulation in biosystem through contaminated water, soil and air (Alloway 1995; Nriagu 1996). Heavy metals mobility is closely related to metal solubility, which is further regulated by adsorption, precipitation and ion exchange reactions in soils. It is very important to investigate the process of soil contamination itself with special attention to available fractions because it directly relates to the management and prevention of soil contamination. However, such predictions under field conditions suffer from much uncertainty. This is partially due to the difficulty in assessing the effects of dynamic soil solution chemistry on trace metal speciation (Jensen et al., 1999). However, changes in soil solution chemistry due to changes in $\mathrm{pH}$, redox potential and ionic strength, may also significantly shift the retention processes of heavy metals by soils (Gerringa et al., 2001, Amrhein et al, 1994; Norrstrom and Jacks, 1998). Soil redox status varies temporally and spatially. In a surface soil, it is influenced by rainfall, bioactivity, and in particular changes in land use. The importance of maintaining an adequate soil nutrition supply to crops in order to maximize agricultural output has long been recognized and the routine application of plant residue to agricultural land have become an integral part of agriculture in developing countries (Withers et al., 2001). Organic mulches can increase, decrease or have no effect upon nutrient levels depending on mulch type, soil chemistry, and particular nutrients of interest. It can also be effective in removing heavy metals from landscape and garden soils (Chalker-Scott, 2007). However, continued long term application of plant residue can lead to accumulation of organic nutrients in surface horizons which will likely influence of soil properties on kinetics of heavy metals release under different land use. Therefore, a better understanding of the the effect of incubation period on heavy metals release to soil properties like $\mathrm{pH}$ and ECEC seem to be an important issue of present day research on risk assessments.

\section{Materials And Methods}

The study was conducted at the Federal University of Agriculture along Alabata road, Abeokuta (Latitude $7^{\circ} 15^{\prime} \mathrm{N}$, Longitude $3^{\circ} 25^{\prime} \mathrm{E}$ ) within a forest savanna transition zone (Salako et al., 2007) in the tropical wet-and dry clime, South Western Nigeria. The study area is characterized by a tropical climate with distinct wet and dry seasons with bimodal rainfall pattern and mean annual air temperature of about $30^{\circ} \mathrm{C}$. The soil at the experimental site was categorized as a well-drained tropical ferruginous soil. The A horizon of the soil is an Oxic Paleudulf of the Iwo series with $83 \%$ sand, 5\% silt and $12 \%$ clay with a pH of 6 considered tolerable by yam (Olasantan, 2007). 


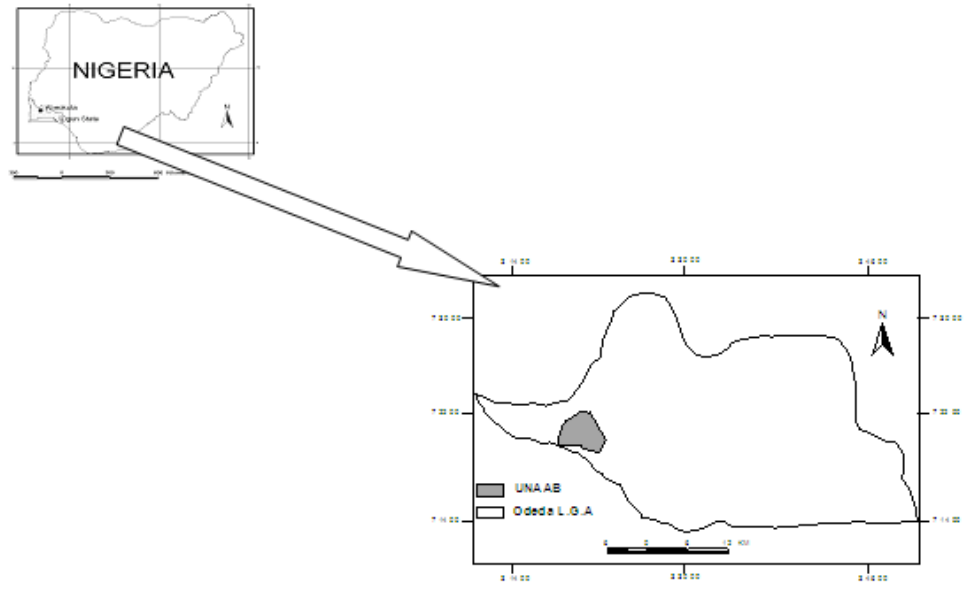

Fig. 1: Location of University of Agriculture, Abeokuta within Odeda Local Government Area in Ogun State, Southwestern Nigeria.

\section{Preliminary Soil analysis}

Six soil samples were collected randomly from different locations at $0-20 \mathrm{~cm}$ depth. The locations included cashew plantation, fadama area, maize cultivated area, grass area, orange farm and forest reserve site. All the six location were cleared and plant residue left on land till about $80 \%$ of plant residue were no longer visile on site. The soil samples in these locations were air-dried, sieved in $2 \mathrm{~mm}$ diameter mesh and analyzed for soil physiochemical properties.

\section{Soil Incubation analysis}

The laboratory incubation study involved one-hundred grams each of soil samples from six experimental locations weighed into cellophane. The heavy metals (cadmium, copper and lead) treatments consisted of three rates $\left(0 \mathrm{~kg} \mathrm{ha}^{-1}(\mathrm{Ro}), 2 \mathrm{~kg} \mathrm{ha}^{-1}\left(\mathrm{R}_{1}\right)\right.$ and $5 \mathrm{~kg} \mathrm{ha}^{-1}\left(\mathrm{R}_{2}\right)$ each in three replicates. The treatments were incubated for eight weeks at field capacity under $25^{\circ} \mathrm{c}$ in the laboratory. After eight-weeks of soil-metal incubation, the soil-metal samples were grounded with a ceramic coated grinder end sieved through a nylon sieve.The final samples were kept in labeled polypropylene containers at ambient temperature.The soil concentations of cadmium, copper and lead in soil were analysed by ratio 5:1.The digestion was performed at a temperature of about $190^{\circ} \mathrm{C}$ for $1.5 \mathrm{hr}$. After cooling the solution was made to a volume of $30 \mathrm{ml}$ with distilled water, and quantified by Flame Atomic Absorption Spectophotometer (FAAS) (Tessier et al., 1979). The digested soil samples from the six locations were also analysed for $\mathrm{pH}$, exchangeable acidity and exchangeable bases. Data collected were subjected to analysis of variance (ANOVA). The sources of variation for the ANOVA were cadmium, copper. lead, $\mathrm{pH}$ and ECEC. The significance of the effects was determined and significant means were separated using DUNCAN multiple range test at $5 \%$ level of probability (Duncan, 1955).

\section{Result And Discussion}

The morphological examination of the soils from the six locations soil samples as presented (Table 1) general showed that, they contain weak aggregates which is probably related to the low clay and organic matter content. The surface texture of the soils showed that the surface soils are loamy sand with exception of the samples from Health-centre site and Colplant research-farm samples that has sandy loam texture on the surface. The texture of the soils as experienced on the field can be said to be as result of the nature of the parent materials which is a principal factor in soil formation (Smyth and Montgomeny, 1962). The $\mathrm{pH}$ values of the soils in all the area indicated that they were under neutral conditions which was within the optimal range for the performance of tomato. Adetunji and Bamiro (1994) however stated that $\mathrm{pH}$ range of 6 to 7 is generally most favourable for plant growth because most plant nutrients are readily available in this range.

The organic carbon was within the the range of $0.78 \%$ to $4.49 \%$ with the highest at the Fadama site. The higher value of organic carbon found in the Fadama area soil might be attributed to the decomposed plant parts that would have mixed with the soil, compared to the other land use soils with low organic carbon. Low organic matter in the soils has been attributed to the return of little or no agricultural residue, high rate of transformation and translocation of organic materials in tropical soils (Ojanuga, 1971; Ekwoanya and Ojanuga, 2002.

The effective cation exchange capacity ranged between 5.33 to $6.62 \mathrm{cmol} \mathrm{kg}^{-1}$ which are generally moderate according to the classification by Adepetu et al. (1979) and Kparmwang et al. (1998) that soils with ECEC less than 4 , range of 4 to 10 and greater than $10 \mathrm{c} \mathrm{mol}^{-1} \mathrm{~kg}^{-1}$ are low, medium and high respectively. The 
moderate ECEC level of these soils can be attributed to clay content (though low potassium). It is therefore important that the organic matter of the soils be well maintained for the ECEC to be improved to a large extent. The total nitrogen ranged between $0.1 \%$ and $8.0 \%$ and the available phosphorus (determine by Bray-1- method) ranged between 1.20 to $3.95 \mathrm{mg} \mathrm{kg}^{-1}$ with the highest value for cashew plantation and fadama respectively. These range is also favourable for plant growth.

At the commencement of the experiment, traces of the heavy metals (cadmium, copper and lead) were present in selected soils from the six locations. The presence of these heavy metals in the soils could be associated with the presence of oxyhydroxides of iron, aluminum and manganese; phyllosilicate minerals; carbonates; and sulphides associated with low clay content of soils (Bolt and Van- Riemsdijk,1987). It could also be due to human activities like exhaut from vehicles from the road side (Arowolo et al, 1999).

Table 1: Some initial properties of experimental soils sample from the six locations .

\begin{tabular}{|c|c|c|c|c|c|c|}
\hline Sample & Fadama & Maize area & Grass area & Forest -site & Orange farm & $\begin{array}{l}\text { Cashew } \\
\text { plantation }\end{array}$ \\
\hline $\mathrm{pH}: \mathrm{H}_{2} \mathrm{O} 1: 2$ & 6.95 & 7.02 & 7.02 & 7.01 & 7.01 & 6.98 \\
\hline O.C $(\%)$ & 4.49 & 0.91 & 1.72 & 1.21 & 1.15 & 0.78 \\
\hline AV. $P\left(\mathrm{mgkg}^{-1}\right)$ & 3.95 & 2.72 & 1.65 & 1.52 & 1.20 & 1.55 \\
\hline ECEC $\mathrm{cmol}^{-1} \mathrm{~kg}^{-1}$ & 5.33 & 6.60 & 6.34 & 6.30 & 6.29 & 6.62 \\
\hline O.M (\%) $\mathrm{mg} \mathrm{g}^{-1}$ & 7.74 & 1.60 & 2.96 & 2.09 & 1.98 & 1.34 \\
\hline T. N $(\%)$ & 1.36 & 1.20 & 0.10 & 1.40 & 1.22 & 8.0 \\
\hline Sand $(\%)$ & 83.1 & 68.6 & 75.6 & 74.8 & 73.8 & 74.6 \\
\hline Clay (\%) & 11.3 & 17.2 & 10.1 & 11.6 & 11.7 & 11.4 \\
\hline Silt (\%) & 5.5 & 13.4 & 13.8 & 13.6 & 13.8 & 13.6 \\
\hline Textural class & Loamy sand & Sandy loam & Sandy loam & Loamy sand & Loamy sand & Loamy sand \\
\hline
\end{tabular}

O.C $=$ Organic Carbon, $\mathrm{T} . \mathrm{N}=$ total nitrogen $\mathrm{AV} . \mathrm{P}=$ available phosphorus, $\mathrm{ECEC}=$ Effective Cation Exchange Capacity, O.M= Organic matter

Tables 2- 4 show the changes in the concentrations of single application of the heavy metals (cadmium, copper and lead) after incubation on $\mathrm{pH}$.The treatment reduced the $\mathrm{pH}$ from neutral to slightly acidic range. This increased in acidic $\mathrm{pH}$ is also not favourable for plant growth because most plant nutrients are not available within this range also the acidity makes the microorganism inactive Ojanuga and Awujoola (1981) attributed this slightly $\mathrm{pH}$ level especially on the surface horizon of the locations to low humus, pollution by acidic gases and annual addition of small quantity of carbonates present in form of harmattan dust.. The effective cation exchange capacity (ECEC) decreased significantly $(\mathrm{p}>0.001)$ but the effects is of different trends for the six location. The ECEC decreases because the metals reacts by cation exchange reaction and held to the negative charge on the soil surface by electrostatic,covalent, columbic force, outer and inner-sphere surface complexation (adsorption) and precipitation. The combination of retaining solid phase and retention mechanism determines the bioavailability and thus potential toxicity of metal ions (Tessier and Campbell, 1987: Thornton, 1991: Doelman and Hanstra 2008).

In general it was observed that increased in application of each metals increased the levels of such metals in the soil samples after eight weeks of incubation that is the effects of singly applied cadmium, copper, lead ions undergoes concentration additive effect on each other. For instance cadmium application from 2 to 5 $\mathrm{kg} \mathrm{ha}^{-1}$ had concentration additive effect on soil cadmium concentration after eight weeks of incubation,same observation was noticed for copper on copper and lead on lead applications, so the effects were concentration dependent (from 2 to $5 \mathrm{~kg} \mathrm{ha}^{-1}$ ).

According to Marschner, (2002) and Kalavrouziotis et al., (2008a), one way synergism involve increasing level of one interacting element resulted in increasing level of the other only while two ways synergistic is the increasing level of one interacting element resulted in increasing level of the other and viceversa. Antagonism involve increasing level of one interacting element resulted in decreasing the level of the other.

Cadmium effect on copper is one way synergism that is, it was observed that increase in application of cadmium has a synergistic effect on copper concentration that is cadmium significantly increased copper concentration with increasing in level ( 2 and $5 \mathrm{mg} \mathrm{kg}^{-1}$ ) of contaminated soils than the untreated soil . ( $0 \mathrm{mg} \mathrm{kg}$ ${ }^{1}$ ) from the locations (Table.2). This may be because copper has higher adsorption than cadmium for the ionic radius of copper is $0.73 \mathrm{~A}$ while that of cadmium is $0.97 \mathrm{~A}$ and the smaller the ionic radius, the greater its affinity to reactive site of the soil. Copper on cadmium is antagonistic effect that is cadmium decreased, with the increase in copper concentration. The application of cadmium has an antagonistic effect on lead that is increase in cadmium concentration decreased lead. Lead application has no significant effect on cadmium for the six locations but synergistic effects on copper (Table 4).

Cadmium and lead interaction showed no significant effects on each other. Lead and copper are interrelated in "two--ways" synergistic interaction where the increase in copper level resulted in the increase in 
lead concentration in the soil and vice-versa. It showed that both treatments affects the bioavailable level of either copper or lead in the soil during their respective interactions and consequently their effects on the interactions (lead on copper or copper on lead) is similar.The environmental significance of synergistic interaction of lead that is non essential element interfering with availability of essential copper is based on the fact that the presence of lead in the soil further enhances mutually the concentration of the other which may be in connection to the $\mathrm{pH}$ change as well as organic matter in the soil. Both copper and lead are complexed by organic matter and proximity of both lead and copper accumulation, possibly favours the synergistic interaction between these two heavy metals. This at very high levels in the soil, may affect adversely plant growth and the agroecological environment. This agrees with Kalavrouziotis et al. (2009) result on the heavy metal interrelationship in soil under treated municipal waste water.

Table 2: Effect of cadmium on soil $\mathrm{Cd}, \mathrm{Cu}, \mathrm{Pb}, \mathrm{pH}$ and $\mathrm{CEC}$ after 8 weeks of incubation

\begin{tabular}{|c|c|c|c|c|c|c|}
\hline & tments $\left(\mathrm{kg} \mathrm{ha}^{-1}\right)$ & Cd & $\mathrm{Cu}$ & $\mathbf{P b}$ & pH & ECEC \\
\hline & na site & & & & & \\
\hline \multirow[t]{3}{*}{0} & 0 & $0.06^{\mathrm{c}}$ & $0.14^{\mathrm{b}}$ & $0.11^{\mathrm{a}}$ & $6.95^{\mathrm{a}}$ & $5.33^{\mathrm{b}}$ \\
\hline & 2 & $0.13^{\mathrm{b}}$ & $0.14^{\mathrm{b}}$ & $0.11^{\mathrm{ab}}$ & $6.90^{\mathrm{a}}$ & $6.17^{\mathrm{a}}$ \\
\hline & 5 & $0.23^{\mathrm{a}}$ & $0.16^{\mathrm{a}}$ & $0.10^{\mathrm{a}}$ & $6.90^{\mathrm{a}}$ & $5.40^{\mathrm{b}}$ \\
\hline \multicolumn{7}{|c|}{ Maize Area } \\
\hline \multirow[t]{3}{*}{0} & 0 & $0.05^{\mathrm{c}}$ & $0.12^{\mathrm{c}}$ & $0.12^{\mathrm{a}}$ & $7.02^{\mathrm{a}}$ & $6.60^{\mathrm{a}}$ \\
\hline & 2 & $0.12^{\mathrm{b}}$ & $0.14^{\mathrm{b}}$ & $0.11^{\mathrm{b}}$ & $6.81^{\mathrm{b}}$ & $5.68^{\mathrm{b}}$ \\
\hline & 5 & $0.25^{\mathrm{a}}$ & $0.16^{\mathrm{a}}$ & $0.11^{\mathrm{b}}$ & $6.80^{\mathrm{b}}$ & $4.71^{\mathrm{c}}$ \\
\hline \multicolumn{7}{|c|}{ Grass area } \\
\hline \multirow[t]{3}{*}{0} & 0 & $0.05^{\mathrm{c}}$ & $0.12^{\mathrm{c}}$ & $0.11^{\mathrm{a}}$ & $7.02^{\mathrm{a}}$ & $6.34^{\mathrm{a}}$ \\
\hline & 2 & $0.12^{\mathrm{b}}$ & $0.14^{\mathrm{a}}$ & $0.11^{\mathrm{ab}}$ & $6.80^{\mathrm{b}}$ & $6.09^{\mathrm{a}}$ \\
\hline & 5 & $0.24^{\mathrm{a}}$ & $0.15^{\mathrm{a}}$ & $0.10^{\mathrm{ab}}$ & $6.80^{\mathrm{b}}$ & $5.18^{\mathrm{c}}$ \\
\hline \multicolumn{7}{|c|}{ Orange farm } \\
\hline \multirow[t]{3}{*}{0} & 0 & $0.06^{\mathrm{c}}$ & $0.13^{\mathrm{c}}$ & $0.12^{\mathrm{a}}$ & $7.01^{\mathrm{a}}$ & $6.30^{\mathrm{a}}$ \\
\hline & 2 & $0.13^{\mathrm{b}}$ & $0.14^{\mathrm{b}}$ & $0.11^{\mathrm{b}}$ & $6.90^{\mathrm{a}}$ & $6.15^{\mathrm{ab}}$ \\
\hline & 5 & $0.24^{\mathrm{a}}$ & $0.16^{\mathrm{a}}$ & $0.11^{\mathrm{a}}$ & $6.90^{\mathrm{a}}$ & $5.43^{\mathrm{b}}$ \\
\hline \multicolumn{7}{|c|}{ Forest-Site } \\
\hline \multirow[t]{3}{*}{0} & 0 & $0.05^{\mathrm{c}}$ & $0.12^{\mathrm{c}}$ & $0.11^{\mathrm{a}}$ & $6.90^{\mathrm{a}}$ & $6.29^{\mathrm{a}}$ \\
\hline & 2 & $0.12^{\mathrm{b}}$ & $0.14^{\mathrm{b}}$ & $0.11^{\mathrm{b}}$ & $6.80^{\mathrm{b}}$ & $6.16^{\mathrm{a}}$ \\
\hline & 5 & $0.24^{\mathrm{a}}$ & $0.15^{\mathrm{a}}$ & $0.09^{\mathrm{c}}$ & $6.70^{\mathrm{c}}$ & $5.40^{\mathrm{b}}$ \\
\hline \multicolumn{7}{|c|}{ CashewSite } \\
\hline \multirow[t]{3}{*}{0} & 0 & $0.05^{\mathrm{c}}$ & $0.13^{\mathrm{c}}$ & $0.12^{\mathrm{a}}$ & $6.98^{\mathrm{a}}$ & $6.62^{\mathrm{a}}$ \\
\hline & 2 & $0.13^{\mathrm{b}}$ & $0.14^{\mathrm{b}}$ & $0.11^{\mathrm{a}}$ & $6.80^{\mathrm{b}}$ & $4.54^{\mathrm{b}}$ \\
\hline & 5 & $0.24^{\mathrm{a}}$ & $0.15^{\mathrm{a}}$ & $0.10^{\mathrm{a}}$ & $6.80^{\mathrm{b}}$ & $4.88^{\mathrm{b}}$ \\
\hline
\end{tabular}

Means with the same superscript are not significantly different at $P \leq 0.05$

Table 3: Effect of copper on soil $\mathrm{Cd}, \mathrm{Cu}, \mathrm{Pb}, \mathrm{pH}$ and $\mathrm{CEC}$ after 8 weeks of incubation

\begin{tabular}{|c|c|c|c|c|c|}
\hline $\begin{array}{l}\text { Treatments (kg ha- } \\
\text { 1) }\end{array}$ & Cd & $\mathrm{Cu}$ & $\mathbf{P b}$ & pH & ECEC \\
\hline \multicolumn{6}{|l|}{ Fadama site } \\
\hline $0 \quad 0$ & $0.15^{\mathrm{a}}$ & $0.12^{\mathrm{b}}$ & $0.11^{\mathrm{b}}$ & $6.95^{\mathrm{a}}$ & $5.33^{\mathrm{b}}$ \\
\hline 2 & $0.12^{\mathrm{b}}$ & $0.13^{\mathrm{b}}$ & $0.11^{\mathrm{b}}$ & $6.89^{\mathrm{a}}$ & $5.81^{\mathrm{ab}}$ \\
\hline 5 & $0.14^{\mathrm{a}}$ & $0.25^{\mathrm{a}}$ & $0.12^{\mathrm{a}}$ & $6.88^{\mathrm{a}}$ & $5.82^{\mathrm{ab}}$ \\
\hline \multicolumn{6}{|l|}{ Maize Area } \\
\hline $0 \quad 0$ & $0.14^{\mathrm{a}}$ & $0.11^{\mathrm{b}}$ & $0.12^{\mathrm{b}}$ & $7.02^{\mathrm{a}}$ & $6.60^{\mathrm{a}}$ \\
\hline 2 & $0.12^{\mathrm{b}}$ & $0.12^{\mathrm{b}}$ & $0.12^{\mathrm{b}}$ & $6.84^{\mathrm{b}}$ & $4.84^{\mathrm{b}}$ \\
\hline 5 & $0.15^{\mathrm{a}}$ & $0.23^{\mathrm{a}}$ & $0.13^{\mathrm{a}}$ & $6.85^{\mathrm{b}}$ & $4.81^{\mathrm{b}}$ \\
\hline \multicolumn{6}{|l|}{ Grass area } \\
\hline $0 \quad 0$ & $0.14^{\mathrm{a}}$ & $0.11^{\mathrm{c}}$ & $0.11^{\mathrm{b}}$ & $7.02^{\mathrm{a}}$ & $6.34^{\mathrm{a}}$ \\
\hline 2 & $0.12^{\mathrm{c}}$ & $0.13^{\mathrm{b}}$ & $0.11^{\mathrm{ab}}$ & $6.81^{\mathrm{b}}$ & $5.78^{\mathrm{a}}$ \\
\hline 5 & $0.14^{\mathrm{a}}$ & $0.23^{\mathrm{a}}$ & $0.12^{\mathrm{a}}$ & $6.82^{\mathrm{b}}$ & $5.30^{\mathrm{a}}$ \\
\hline \multicolumn{6}{|l|}{ Orange farm } \\
\hline $0 \quad 0$ & $0.16^{\mathrm{a}}$ & $0.11^{\mathrm{b}}$ & $0.12^{\mathrm{b}}$ & $7.01^{\mathrm{a}}$ & $6.30^{\mathrm{a}}$ \\
\hline 2 & $0.12^{\mathrm{b}}$ & $0.12^{\mathrm{b}}$ & $0.11^{\mathrm{b}}$ & $6.89^{\mathrm{b}}$ & $5.66^{\mathrm{b}}$ \\
\hline 5 & $0.14^{\mathrm{b}}$ & $0.24^{\mathrm{a}}$ & $0.13^{\mathrm{a}}$ & $6.88^{\mathrm{b}}$ & $5.54^{\mathrm{b}}$ \\
\hline \multicolumn{6}{|l|}{ Forest-Site } \\
\hline $0 \quad 0$ & $0.15^{\mathrm{a}}$ & $0.11^{\mathrm{c}}$ & $0.11^{\mathrm{b}}$ & $6.90^{\mathrm{a}}$ & $6.29^{\mathrm{a}}$ \\
\hline 2 & $0.12^{\mathrm{c}}$ & $0.12^{\mathrm{b}}$ & $0.11^{\mathrm{b}}$ & $6.85^{\mathrm{b}}$ & $5.82^{\mathrm{a}}$ \\
\hline
\end{tabular}




\begin{tabular}{cccccc}
\hline \multicolumn{1}{c}{5} & $0.14^{\mathrm{b}}$ & $0.22^{\mathrm{a}}$ & $0.13^{\mathrm{a}}$ & $6.80^{\mathrm{b}}$ & $5.41^{\mathrm{b}}$ \\
\multicolumn{1}{c}{ CashewSite } & & & & & \\
$0 \quad 0$ & $0.15^{\mathrm{a}}$ & $0.12^{\mathrm{b}}$ & $0.11^{\mathrm{b}}$ & $6.98^{\mathrm{a}}$ & $6.62^{\mathrm{a}}$ \\
2 & $0.12^{\mathrm{c}}$ & $0.13^{\mathrm{b}}$ & $0.11^{\mathrm{b}}$ & $6.86^{\mathrm{ab}}$ & $3.99^{\mathrm{b}}$ \\
5 & $0.13^{\mathrm{b}}$ & $0.22^{\mathrm{a}}$ & $0.12^{\mathrm{a}}$ & $6.84^{\mathrm{b}}$ & $3.98^{\mathrm{c}}$ \\
\hline
\end{tabular}

Means with the same superscript are not significantly different at $\mathbf{P} \leq 0.05$.

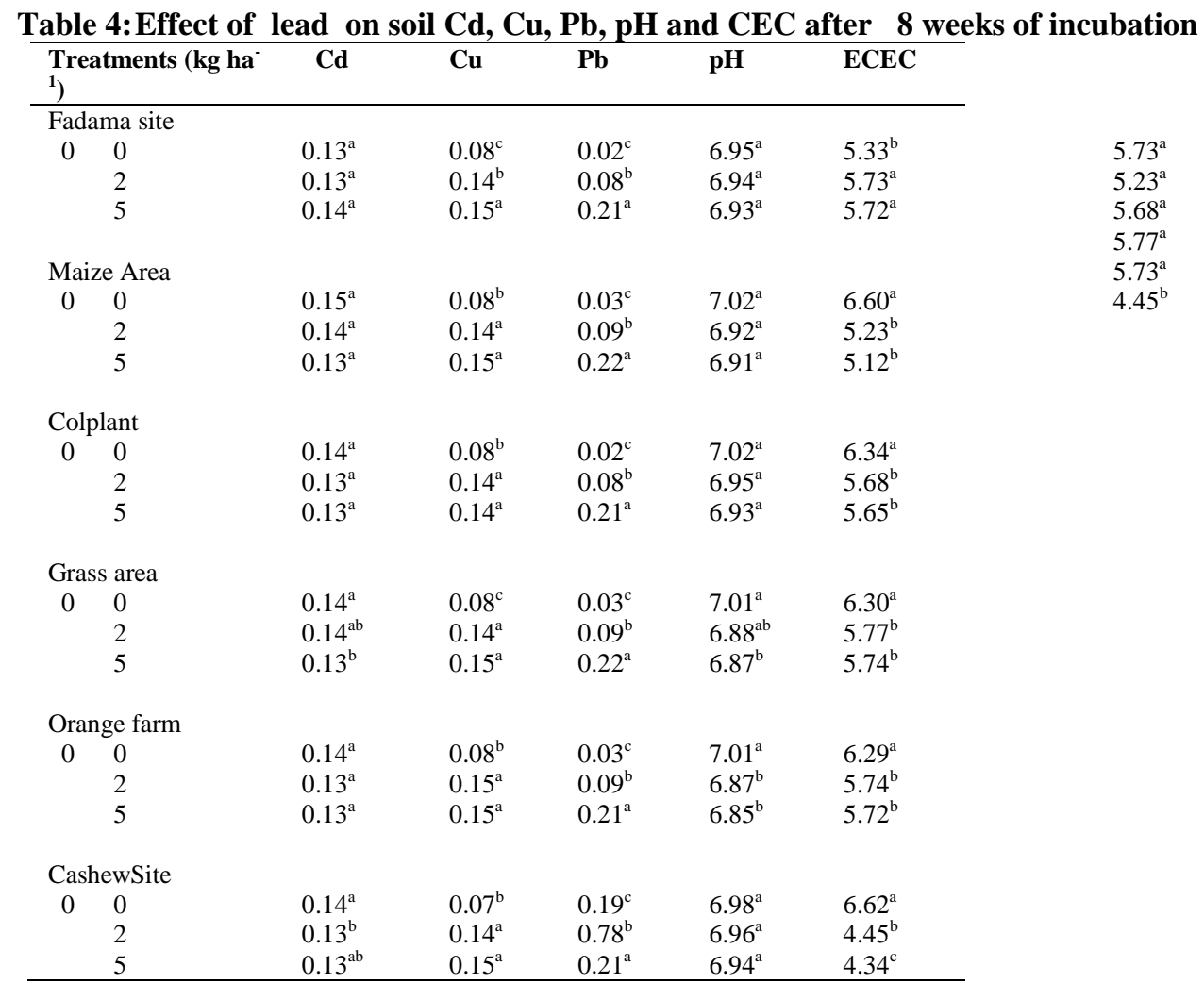

Means with the same superscript are not significantly different at $\mathbf{P} \leq 0.05$.

\section{Conclusion}

The effect of single application of heavy metals on soil incubation changes the $\mathrm{pH}$ from neutral to slightly acidic $\mathrm{pH}$ and had significant reduce the ECEC of the soil from the six locations.The individual treatments of cadmium, copper and lead produced all the three types of effects, synergism, antagonism and concentration additive effects on each of the residual metals concentrations in the incubated soils.

\section{Reference}

[1]. Adepetu, J.A., Adebayo,A.A., Aduayi, E.A. and Alofe, G.O. 1979. A preliminary survey

[2]. of the fertility status of soils in ondo state under traditional cultivation. Ife Journal of Agric 1: 134-149.

[3]. Adetunji, M.T. and Bamiro, F.O.1994. Effect of lime addition on soil properties, nitrogen

[4]. nutrition and nutrient uptake in some Nigerian soils. African Crop Science Journal 2(2): 183-187.

[5]. Alloway B.J. 1995. Heavy metals in soils. Blackie Academic and professional. An importance of Chapman and Hall London.

[6]. Amrhein, C., Mosher, P.A., strong, J.E., Pacheco, P.G., 1994. Trace metal solubility in

[7]. soils and waters receiving deicing salts. J. Environ. Qual.23, 219 e 222.

[8]. Arowolo I.A Bamgbose O, Odukoya .O.O. 1999. The chemical form of lead in roadside dust of metapolitan, Lagos, Nigeria Journal of Pure and Applied Science 6 (3):483-487.

[9]. Chalker-Scott, L. 2007. Impact of Mulches on Landscape Plants and the Environment - A Review.J. Environ. Hort. 25(4): $239-249$.

[10]. Chirenje, T., Ma, L.Q., Clark, C., Reeves, M., 2003. Cu, Cr and As distribution in soils adjacent to pressure-treated decks, fences and poles. Environ. Pollut. 124, 407 e 417.

[11]. Ducan, D.B.1955.Multiple Range and Multiple F-test. Boimetrics 11:1- 42.

[12]. Ekwoanya, M.A. and Ojanuga, A.G. 2002. Productivity assessment of upland and flood plains soils at Markurdi, Nigeria. Geoderma 108. Pg 19-29.

[13]. Gerringa, L.J.A., de Baar, H.J.W., Nolting, R.F., Paucot, H., 2001. The influence of salinity on the solubility of Zn and Cd sulphides in the Scheldt estuary. J. Sea Research 46, $201 \mathrm{e} 211$.

[14]. Kalavrouziotis, I.K., Koukoulakis, P.H., Robolas, P.K., Papadopoulos, A. H. and Pantazis.V. 2008a. Essential plant nutrient interactions in a soil cropped with Brassica oleracea variety. Italica,irrigated with Teated Municipal Waste water and their environmental implications, FreseniusEnviromental Bulletin. 17(9a): 1272-1280.

[15]. Kalavrouziotis, I.K., Koukoulakis, P.H., Papadopoulos, A.H., 2009.Heavy metal interrelationship in soil in the presence of treated municipal waste water. 
[16]. Global-Nest Journal.11(4)497-509.Kparmwang, T., Abubakar, A.S., Chude, V.O., Raji, B.A. and Malgwi, W.B. 1998. The inherent fertility and management of the micro topographical land features of the

[17]. river Galma Fadama at Zaria. In: Soil management for sustainable agriculture and Environment Harmony, $24^{\text {th }}$ SSSN Proceedings pp 125-130.

[18]. Lal, R. 1986. No tillage farming: Soil and Water conservation and management in the humid and sub-humid tropics. IITA Monograph No 2, Ibadan.

[19]. Ma, Q.Y., Logan, T.J., Traina, S.J., 1995. Lead immobilization from aqueous solutions and contaminated soils using phosphate rocks. Environ. Sci. Technol. 29, 1118e1126.

[20]. Marschner. H. 2002. Mineral Nutrition of Higher plant, $2^{\text {nd }}$ Edition, Academic press, Amterdam.Norrstrom, A.C., Jacks, G., 1998. Concentration and fractionation of heavy metals in roadside soils receiving de-icing salts. Science Total Environ. 218, 161e174.

[21]. Nriagu, J. and Kim, M.J. 2000. "Emissions of lead and zinc from candles with metal-core wicks". Journal of Science of the Total Environment $250(1-3): 37$.

[22]. Ogunwole, J.O, Babalola, O.A, Oyinlola, E.Y and Raji B.A 2001.Pedological characterization of soil in the Samaru Area of Nigeria. Samaru Journal of Agricultural Research, Vol. 17.

[23]. Ojanuga, A.G.,1971.A study of soil and soil genesis in the southwestern upland of Nigeria Ph.D Thesis University of Wisconsin, Madison, Wis., U.S.A.

[24]. Ojanuga, A.G., and Awujoola, A.I., 1981. Characteristics and classifications of the soils of the Jos Plateau, Nigeria. Nigeria Journal of Soil Science. 2 : 101-119.

[25]. Olasantan, F.O. 2007. Effect of population density and sowing date of pumpkin on soil hydrothermal regime, weed control and crop growth in a yam -pumpkin intercrop. Experimental Agriculture 43: 365-380.

[26]. Post, W.M., and Mann, L.K. 1990. Change in soil organic carbon and nitrogen as a result of cultivation. In: Bouwman. A.F. (Ed), Soils : the Green House Effect. Wiley, New York, pp. 401-406.

[27]. Salako, F.K., Dada, P.O, Adejuyigbe, C.O., Adedire, M.O., Martins, O. Akwuebu, C.A. and Willams, O.E. 2007. Soil strength and maize yield after top soil removal and application of nutrient amendment on a gravelly Alfisol toposequence. Journal of

[28]. Soil and Tillage Reseach 94: 21-35.

[29]. Smyth, A.J. and Mongomery, R.F. 1962. Soils and land use in Central Western Nigeria Government Press, Ibadan.

[30]. Tessier, A., Campbell, P.G.C. and Bisson.M. 1979. Sequental extraction procedure for the speciation of particulate trace metals. Journal of Analytical Chemistry 51 (7): 844-851

[31]. Tessier, A. and Campbell, P.G.C.1987. Partitioning of trace metals in sediments: relationship with bioavailability.Ecological effects of in situ sediment contaminant, Journal of Hidrobiology,149;43-51.

[32]. Thornton, I. 1991. Metal contamination in soils of urban Areas In: soils in the urban environment. P Bullock and P. Journal Gregory (eds). Blackwell, Oxford. 47-75pp. 